\title{
Review
}

\section{Strategic Innovation, Foresight and the Deployment of Project Portfolio Management under Mid-Range Planning Conditions in Medium-Sized Firms}

\author{
Nick Hadjinicolaou ${ }^{1, *}$, Mohamad Kader ${ }^{2}$ and Ibrahim Abdallah ${ }^{1}$ \\ 1 Torrens University Australia, Global Project Management, \\ Adelaide, SA 5000, Australia; ibra-him.abdallah@torrens.edu.au \\ 2 Consultica Worldwide Management Consultants, Sydney, NSW 2000, Australia; m.kader@consultica.com.au \\ * Correspondence: nhadjinicolaou@torrens.edu.au
}

check for updates

Citation: Hadjinicolaou, N.; Kader, M.; Abdallah, I. Strategic Innovation, Foresight and the Deployment of Project Portfolio Management under Mid-Range Planning Conditions in Medium-Sized Firms. Sustainability 2022, 14, 80. https://doi.org/ $10.3390 /$ su14010080

Academic Editor:

Fabrizio D'Ascenzo

Received: 24 November 2021

Accepted: 18 December 2021

Published: 22 December 2021

Publisher's Note: MDPI stays neutral with regard to jurisdictional claims in published maps and institutional affiliations.

Copyright: () 2021 by the authors Licensee MDPI, Basel, Switzerland. This article is an open access article distributed under the terms and conditions of the Creative Commons Attribution (CC BY) license (https:/ / creativecommons.org/licenses/by/ $4.0 /)$.

\begin{abstract}
The purpose of this paper is to examine the ability of a firm to innovate and absorb its innovative developments by borrowing concepts and models from project portfolio management (PPM). Using past research and the existing literature, it evaluates the potential to apply PPM to the medium-term strategic planning efforts of small- and medium-sized firms. The implementation of strategic innovation requires organizations to develop both a dynamic culture and flexible internal systems that yield to major external changes in their industry as well as internal resource changes. Such changes could include supply or value chain adjustments, changes in consumer behavior, reallocation of internal resources or the responses of competitors. This paper examines the planning and implementation of project portfolio management tools in small- and medium-sized enterprises (SMEs) (50-250 employees) with a mid-range (2-4 years) planning horizon that are required to innovate in a strategic context to remain competitive or to take advantage of new opportunities. It relates strategic foresight to the ability of the firm to adjust tactically, including in the utilization and development of internal tools, processes, systems and culture. This paper contributes to the literature by examining the potential for PPM methodologies and models to support decision making in a strategic context in SMEs, an area that is under-represented in the research on strategy. It also relates this foresight with strategic innovation and draws parallels between the strategic management planning process and the use of project portfolio management models. It argues that strategic innovation is closely tied with the ability not just to innovate but to absorb this innovation within the organizational processes and build organizational maturity. It also examines the potential use of project portfolio management models to aid strategic innovation. The use of PPM models in support of strategic innovation may contribute to the sustainability of SMEs as businesses and to the potential to identify new business models that enhance the sustainability of a firm's competitive advantage, particularly in the medium-term.
\end{abstract}

Keywords: strategic innovation; project portfolio management; organizational assets; strategic project management

\section{Introduction}

A critical component of success in business is strategic innovation. Strategic innovation has been described as the fundamental reconceptualization of business models and the reshaping of existing markets by breaking the rules and changing the nature of competition [1]. It refers to the ability of a firm to open new markets, address competitors' moves, and create value for customers [2]. Innovation in strategy can focus on planning or execution. This study concerns itself with the execution of a strategy, with particular emphasis on small- and medium-sized firms. It considers the utilization and maximization of resources in the context of project portfolio management (PPM) and proposes a different perspective on innovation, one that takes into account the challenges facing medium-sized firms in their execution of strategic intent. 
Strategic planning has been integrated into the project and portfolio management function for more effective PPM [3], which has resulted in efficiency and effectiveness gains [4-6]. The challenges of strategic planning in small- and medium-sized businesses include sustainability [7], planning cycles [8], and performance measurement [9]. The use of strategic planning tools can improve the efficacy of strategic plans for SMEs, including planning, implementation, and reviews of strategies [10-12]. Various models have been proposed that can aid in the development of strategies $[13,14]$, but there remain major challenges for SMEs in the creation of market opportunities.

Examining the potential use of PPM frameworks in strategic planning for SMEs may present opportunities for enhancing strategic foresight for these firms. This challenge is exemplified in the need for strategic innovation to address changes in markets, competitor behavior, and consumer preferences, a similar set of challenges faced in project portfolio management. This paper also assumes that the portfolio of projects is sufficient to justify the use of PPM within the organization, as is the level of project management maturity which will be discussed.

According to Tse [15], "while deliberate strategies involve strategic planning and formulation, emergent strategies respond to the unanticipated chaotic requests of those customers that do not fit the existing strategy. Hence, an emergent strategy reflects a company's responsiveness and its ability to create new logics out of chaos, which enable it to be more successful than its rivals" [15]. Strategic innovation is, therefore, a precursor to mid-term planning in environments that are subject to constant change in the competitive landscape, such as in small- and medium-sized businesses.

Strategic innovation has been linked to changes in a firm's business model to address external market pressures [16] and managing the knowledge of the organization to increase its agility [17]. It has been shown to be one of the most challenging forms of strategic planning even for well-established firms [18] and one that firms need in times of change [19]

Project portfolio management models aid in the planning, implementation, and monitoring of programs and projects, affording greater flexibility that supports client project objectives [20-22]. While each of these models have their strengths and weaknesses and are targeted at various organizations and project types, they can provide a level of project analysis that enhances deployment and project innovation [21,23,24]. For example, the Axelos model, which originates from the UK government and an organization that is responsible for developing, enhancing, and promoting a number of best practice frameworks, has a target audience of large-scale government and other sectors and is highly prescriptive.

The Project Management Institute (PMI) standard is much more generic and descriptive in nature and lacks some of the detail covered in the Axelos standard. The Association for Project Management (APM) model, although it embeds strategic planning and strategy delivery, is not as sophisticated as the PMI or Axelos frameworks. However, it specifies the required cycle from strategic planning to strategic delivery. Among the benefit of these models is that they are able to improve management foresight, mid-range planning, and strategic innovation [25-28]. Borrowing concepts from these models in the context of strategic planning and innovation for the broader firm may provide opportunities to develop better strategic foresight and aid the planning horizon range (2-4 years) and the deployment of projects in small- and medium-sized enterprises (SMEs) (50-250 employees) as well as serve as a strategic management tool for such organizations. This paper examines the various project portfolio management models, their potential utility in strategic innovation and foresight, and their application to strategic planning. It also reviews their potential use in the implementation of project portfolio management (PPM) in conditions where SMEs adopt a mid-range planning horizon of 2-4 years.

The performance of firms, often restricted by resources and the time horizon of feasible foresight of markets, is often correlated with this ambidexterity that combines current and future plans [29]. By applying the principle of ambidexterity to SMEs, it is possible that for the firm to improve its strategic foresight, it needs to consider its resources and its strategic intent not only from a planning perspective but also in terms of strategy execution. 
This paper examines the literature with respect to strategic innovation, foresight, and the potential to borrow principles of project portfolio management in executing SME strategies.

This paper forms part of a broader research effort that will test the ability of small- and medium-sized enterprises (SMEs) to apply PPM principles as part of strategic planning with the goal of improving management decision making and organizational agility. This paper explores some of the literature covering PPM principles and the potential to use these to execute strategies in areas of opportunity. While this paper does not utilize data, it forms part of a larger body of work underway to test the theoretical concept in the field in subsequent studies.

This paper also provides a review of the Project Management Institute (PMI) project maturity model as a PPM tool and examines the potential application of PPM in SME strategies.

PPM provides a solution to align strategic objectives with projects and deliver an organization's strategy through the centralized management of one or more programs and portfolios [30,31].

This paper makes a valuable contribution in two strands of the literature. First, it examines the planning and implementation of project portfolio management tools in organizations with a mid-range (2-4 years) planning horizon who are required to innovate in a strategic context to remain competitive or to take advantage of new opportunities. Secondly, it aims to further review project portfolio management models, the influence of organizational maturity and maintaining a balance between the utilization of organizational assets, and the benefits achieved from strategic agility.

Furthermore, the practical implication of this work is the potential for SMEs to use existing PPM tools and methods to enhance their ability to apply strategic foresight, to plan, and to potentially achieve a form of ambidexterity in their current and future markets.

The remainder of this paper is structured as follows. Section 2 covers the background and research method, Section 3 contains the discussion, and the conclusions are in Section 4.

\section{Background and Research Method}

This study does not include the collection of the primary results, but it provides a review of the literature examining strategic foresight, innovation, and the ability of the firm to deploy a strategy by comparing it with well-established principles borrowed from project portfolio management (PPM). It is focused on the current literature in this space.

Strategic innovation allows a business to compete differently in the same market by re-conceptualizing products and services [18]. Strategic foresight, on the other hand, "is the ability to create and sustain a variety of high quality forward views and to apply the emerging insights in organizationally useful ways; for example, to detect adverse conditions, guide policy, shape strategy; to explore new markets, products and services" [32]. When compared with project portfolio management, which focuses on the utilization of resources and assets to achieve the best return on investment [33], the relationship between the creation of new markets and the utilization of resources can be seen as a factor that influences the decision-making process of medium-sized firms [34].

Strategic planning has been a challenge for medium-sized firms not only due to limited resources but also the length of market forecasting that these firms are able to exercise [35]. Yes, it is these firms that suffer the most from shortages in agility, particularly during difficult market conditions [36]. Organizational agility "encompasses the aptitude to successfully respond to changes in the surrounding environment" [37], enabling firms to better plan, design, and resource a strategy [38].

The use of strategic planning coupled with operational planning has been used to attempt to achieve a balance for the firm for both its existing business and its future direction. This concept of an ambidextrous organization has been cited as an example of the organization's ability to apply foresight with the goal of producing revolutionary products and services while, at the same, resourcing the evolutionary product development process 
that sustains current markets [39]. It has also been used to identify the best utilization of current and future resources to best position an SME [40].

A project portfolio is "a collection of projects, programs and operational work to meet strategic objectives" [41]. Project portfolio management is a means to deliver value to an organization and improve resource utilization. PPM also aids decision making in selecting the right projects to maximize resource allocation, manage portfolio risks, and improve a project's success. These factors align with strategic planning frameworks and the allocation of resources to a strategy [22,42]. To achieve this strong strategic portfolio, execution is required to maintain organizational competitiveness, which indicates parallels between PPM and strategic planning.

The adoption of PPM as a project framework by SMEs can potentially improve planning practice, resource allocation, and decision making within the SME context, particularly in mid-range planning horizons [43,44]. The PMI advocates for continuous improvement through the use of maturity assessment and improvement plans to improve the level of PPM maturity, which is also an opportunity within SME operations to review the ability of the firm not just to implement projects but also to improve manager foresight by drawing on the lessons learned from projects and the use of PPM in strategic planning. Maturity in a PPM context reflects well on the level of strategic maturity of the firm, the ability of management to plan, and the level of strategic innovation the firm undertakes $[45,46]$.

This concept is summarized in Figure 1.

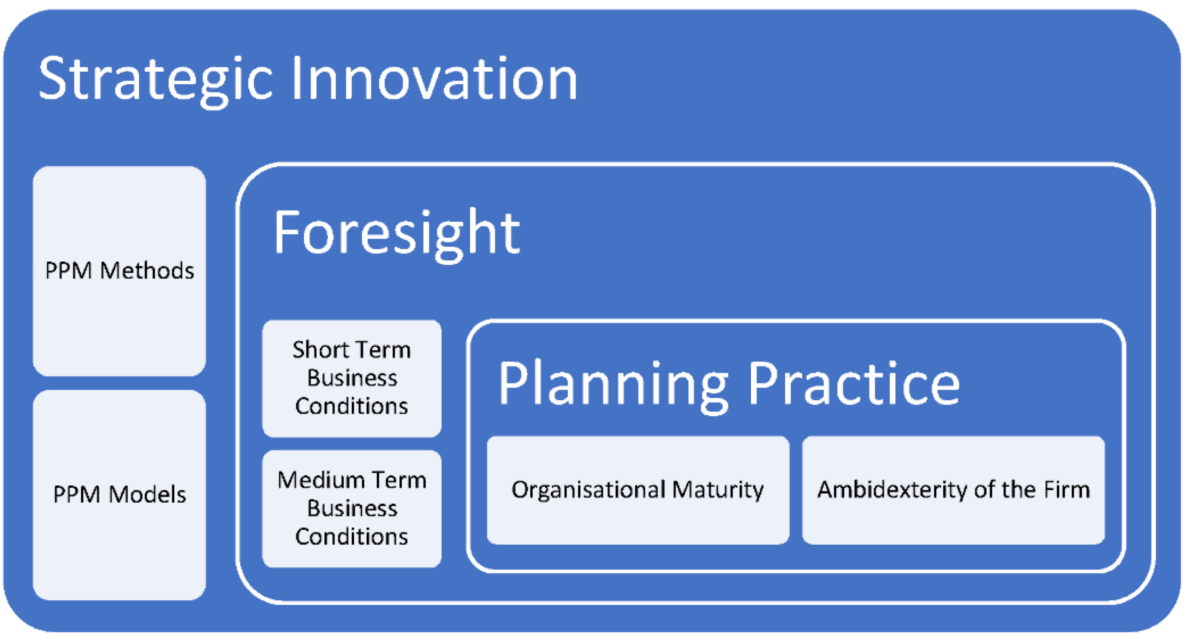

Figure 1. The relationship between strategic innovation within the firm, the application of strategic foresight, and the use of PPM methods as a strategic planning tool.

\section{Discussion}

The performance measurement of PPM requires the selection of suitable metrics and a baseline component of the PPM framework. Organizations at low levels of maturity will require a greater level of initial work than organizations with higher levels of project management maturity. PPM process metrics will be required to drive maturity and support the implementation of PPM. This means that by implementing PPM, SMEs are able to more practically identify their level of maturity and, hence, the capabilities of their resources, both of which are ingredients of strategic planning and mid-range decision making [47,48].

Maturity models in computer science are well-established and have emerged through the Carnegie Melon University Capability Maturity Model. These models from computer science have been extended into the realm of project management and used for evaluating an organization's project management maturity $[49,50]$. The capability of the SME with respect to its intended mid-range strategy can be better understood by management using PPM principles as a strategic management tool [51,52]. The increase in strategic foresight brought about by the use of PPM maturity models within the wider business may improve 
the competitiveness of the organization on the basis of a better understanding of what it is actually "mature".

The Project Portfolio Management Maturity Model developed by PM Solutions is an example of a two-dimensional model that follows the Carnegie Melon levels of maturity. It has five levels of process maturity (initial, structured, institutionalized, managed, and optimized) for six PPM process areas (governance, project opportunity assessment, project prioritization and selection, portfolio and project communication management, portfolio resources, and performance management).

The PMI identifies five levels of portfolio management maturity (PfMM). Figure 2 illustrates the potential interplay between PPM principles, the firm's agility, and their ability to execute a strategy.

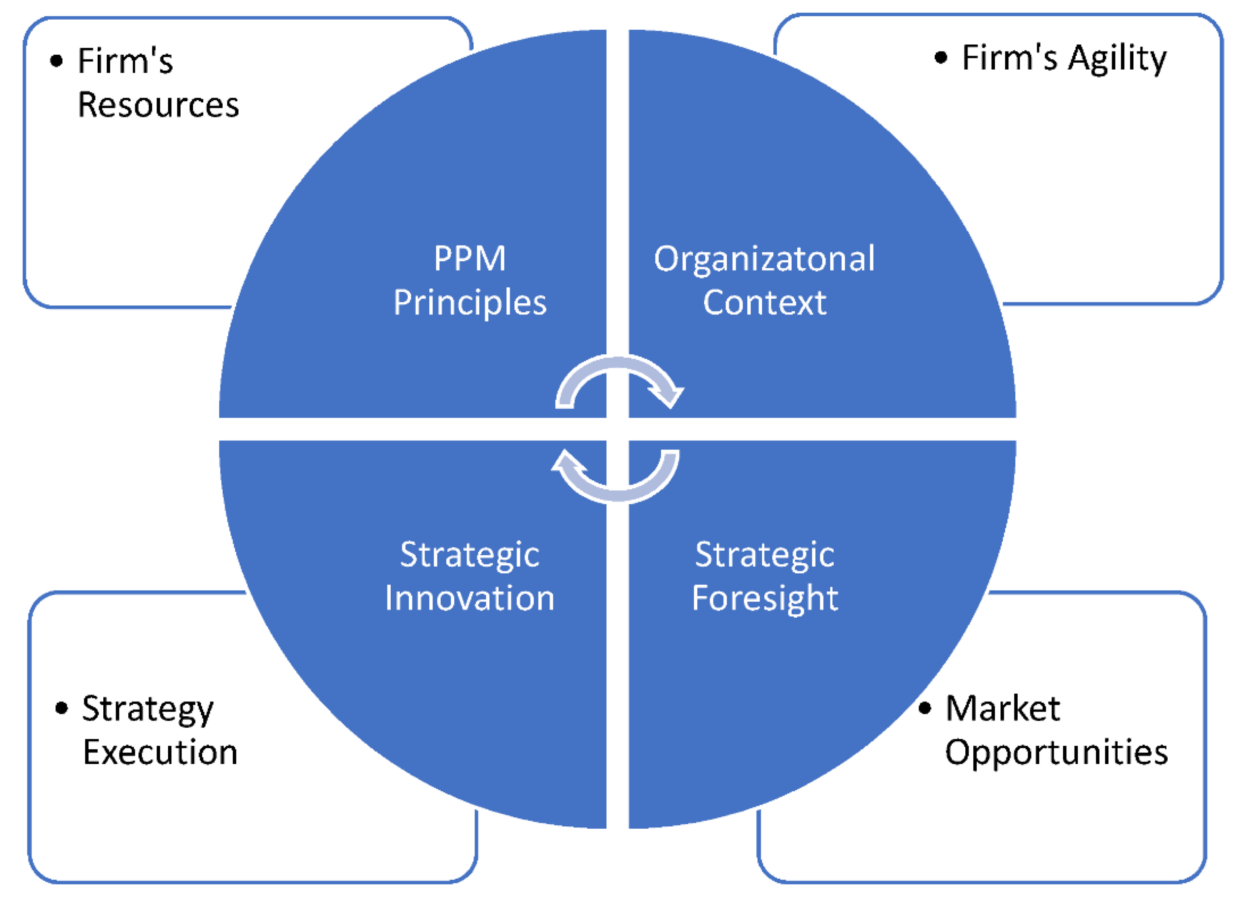

Figure 2. Interplay between PPM principles, the firm's agility, and their ability to execute a strategy.

The maturity level of SMEs with regard to mid-range strategic planning and the foresight needed by SME managers to undertake it can be compared with the Portfolio Management Maturity Model (PfMM), giving rise to an opportunity for SMEs to examine the PfMM as a decision-making tool for business strategies.

At level 1, there are no portfolios established. At level 2, some elements are established. At level 3, there are formal PPM processes in place. At level 4, there are tools to track value and interdependencies. Finally, at level 5, PPM is a core competency resulting in competitive advantage through strategy.

Other benefits derived from PPM maturity include organizations becoming more efficient, agile, risk-averse, resilient, innovative, strategically focused, and motivated through aiming to maximize and sustain PPM implementation by achieving a high level of PPM maturity $[47,53]$. The flexibility of an SME can help its ability to maneuver in a range of business situations, improving its chances of success in mid-term [54,55].

Moving from project management maturity, with its goal of achieving a cost benefit and return on investment (ROI) from projects, was introduced by Ibbs and Kwak [56] as PMM/ROI, and the topic of PPM benefits from portfolio management maturity has become an area of increased interest among practitioners and academics.

Young, Young, and Zapata [57] stated that "organizational governance, stakeholder management, management control, risk management, benefits management, and portfolio, financial and resource management" are the key PPM maturity attributes. Their 
study showed that attaining PPM maturity relies on "a set of knowledge, skills, tools and techniques applied to a collection of projects in order to meet or exceed the needs and expectations of an organization's investment strategy". This has implications for SMEs, as it shows the potential gains in planning ability that can be derived from the use PPM and PfMM.

Thus, the levels of project and portfolio management maturity are important aspects for the deployment of a PPM framework for the implementation of PPM to support a project's success and SME strategic planning success. PPM models emphasize organizational maturity as an element of project and portfolio success. A parallel can be drawn between this emphasis and the need in strategic planning for maturity in the market approach the firm takes and in its competitive advantage. This raises the prospect of PPM models being used in strategic planning, given the level of detail within these models and the systematic way in which they address organizational maturity.

The maturity of a project's organization impacts strategic success and the implementation of PPM [58-60], which in turn affects the strategy. Maturity is measured both at the organizational and the strategic planning levels [61-63]. The success of strategic project implementation is also connected to the application of knowledge [64] and to performance assessment [65]. These links provide insight into the importance of planning tools for the creation of strategic opportunities at the project and business levels [66-69]. The potential for SMEs to apply PPM tools and frameworks in planning and implementing strategy may further their ability to identify new strategic opportunities.

\subsection{Challenges of Implementing PPM to Support SME Planning Success}

However, the implementation of PPM is not straightforward, with a number of barriers in PPM as highlighted by Hadjinicolaou and Dumrak [70]. The challenges for the implementation of PPM include the lack of broad organizational support due to lack of a developed business strategy, lack of executive sponsorship, higher priority organizational and change management issues to address, lack of an organizational unit responsible for managing the process, difficulty to agree on a common approach to prioritize projects, impact on existing processes, and unavailability of systems that provide timely data to measure projects. Furthermore, regarding the immaturity of project management processes, internal politics and a culture of resistance to change, together with shifting business priorities, can also cause significant barriers to the implementation of PPM.

A number of these challenges can be overcome through the implementation of a strategic management office (SMO) that supports the implementation of PPM and provides the required governance and change management to engage with senior executive sponsors for the implementation and support of PPM and associated technology. This would also include support through training, stakeholder and risk management, as well as support with strategic planning and innovation.

An indication of some of the tools that could be used to support the challenges of implementing PPM could include a portfolio dashboard, a portfolio pipeline, and a bubble chart to support the decision-making process, as well as a stage gate process to support governance together with an implementation roadmap to support the staged implementation of PPM.

The lack of real-time data as one of the barriers to the implementation of PPM falls in the category of technology and careful consideration of a suitable strategic management system to not only track project completion but also track the delivery of a strategy and the benefits expected from it. Furthermore, the PPM goals of supporting project success would also be another consideration to overcome the barriers to PPM support.

For small- and medium-sized businesses (SMEs), the development of organizational resilience can improve the potential to apply strategic planning tools, particularly during times of crisis [71]. This is of particular importance given the sensitivity of SMEs to external changes and the need to identify and pivot toward new opportunities when there is a shortage of suitable markets [72]. Of the various steps to improving resilience, 
strategic planning and a stock take of internal resources have been found to be of major significance [73]. The use of planning frameworks has been found to be a major contributor to the development of resilience [74,75].

External shocks that expose SMEs to resource "crunch" have been found to negatively affect organizations that lack the planning depth and foresight to identify possible new areas of business in the face of such shocks [76], as has the approach of owners and entrepreneurs to the use of such tools [77]. This perspective on resilience has been found to reduce the impact of business turbulence on the SME [78], lending weight to the argument that SMEs could utilize PPM planning frameworks as a strategic design and implementation tool $[79,80]$.

Organizational agility arises from the ability of the SME to use a range of tools, including business intelligence [81], planning frameworks [82], the identification of sources of competitive advantage through appropriate resource allocation [83], and strategic foresight [84]. The viability of the business model of an SME can be examined in the context of its ability to design a strategy [85] and measure its performance using strategic planning tools [86]. Both help increase SME dynamism in mid-term [87].

A study by Hadjinicolaou and Dumrak [70] identified that projects are increasingly initiated by organizations in alignment with the corporate strategies. Concerned over the constrained resources and rapid changes that exist in the project environment, project portfolio management (PPM) can support organizations in prioritizing and selecting the right projects to meet strategic objectives and improve project success rates. Among the benefits of PPM, improved decision making, maximizing resource usage, alignment with the business strategy, and organizational risk reduction are the most common benefits found when implementing PPM. On the other hand, internal politics and culture, lacking organizational management support, and disagreement on a common project prioritization approach are the main barriers impeding the application of PPM. Drawing parallels with strategic planning in SMEs, these benefits and barriers may help identify best practice approaches to the utilization of PPM tools to identify and take advantage of market opportunities.

The ability of SMEs to plan future strategies relates to the internal resources of the firm as well as the external environment. The tools needed to ensure internal and external analyses are undertaken with rigor are often absent in the SME space. There are also limited tools available to SMEs that are within a reasonable cost and complexity to allow for management to apply strategic foresight to them in devising strategic plans. The possible use of PPM frameworks and tools that already exist may fill this gap. The use of PPM tools provides an opportunity for SMEs to not only identify the internal and external factors that can affect their strategic direction, strategy intent, and competitive stance, but also the maturity level within the organization that allows the strategy to be developed and implemented.

PPM frameworks help align the strategic direction of the organization with its resources, its organizational structure, its business models, and its supply and value chains. This has mostly been the domain of larger organizations with greater levels of sophistication and resourcing. However, adopting existing PPM frameworks may democratize these tools and allow for their use in SME medium-range strategies. Not only is the use of frameworks for strategic planning useful in achieving greater business model sustainability [88] but also in value creation and the enhancement of the SME value chain [89]. The use of planning frameworks and tools has also been associated with a greater technical ability and the migration of SMEs to more productive technology [90] and improvement in the levels of corporate entrepreneurship [91]. Applications of strategic planning using tools and frameworks have achieved success in SME incubators [92], business model innovation [93], and the creation of a managerial enterprising mindset [94].

The adoption of a PPM framework and tools by SMEs for mid-range strategic planning will also depend on the attitude of management toward resilience, agility, strategic foresight, and change management. For example, alignment of a strategy with management thinking with its development using accepted tools and frameworks has been associated with 
increasing the internal sources of corporate innovation [95]. Newly established SMEs that are created in response to major market gaps or as a disruptor in their field are less systematic in their use of frameworks pre-launch but become more sophisticated in their use of these frameworks as they expand [96]. This extends to the level and type of competitive stance in response to competitors. The better planned the strategy, and the more it is developed using an accepted framework, the more likely it is to be implemented [97,98]. There is, therefore, a possible opportunity for SMEs to take advantage of existing, working frameworks and tools used in PPM and to apply them to their mid-range strategic planning efforts.

\subsection{Goals of PPM to Support Project Success and SME Planning Success}

Among the objectives of PPM are supporting project success and maximizing the return on investment within the portfolio of projects, as well as linking the projects within the portfolio to the firm's strategy and balancing projects within the resource capacity and capability of the organization [99].

PPM success consists of both the success of projects within the portfolio as well as delivering the strategy for future organizational success. Similar goals for PPM success are described by Arlt [100], revealing four distinctive goals for the general objective of maximizing organizational benefits through the optimization of projects with the portfolio.

These four PPM goals are "strategic alignment, portfolio balance, portfolio benefit maximization and improvement" of PPM process maturity [100]. As Arlt [100] describes, if these goals are achieved, then PPM is successful. These goals align with the mid-term strategic planning horizon for SMEs, indicating that the possible use of PPM tools may aid in the planning and execution of a strategy.

Arlt [100] also describes the addition of the fourth goal being that of PPM process maturity. The fourth goal was a result of portfolio governance research [101] that provided evidence in support of the relevance of alignment of projects to strategy, balancing projects within the portfolio, and maximizing project benefits. Blomquist and Müller [102] also proposed that a goal of PPM success was PPM process maturity.

SME planning has often suffered from a lack of strategic depth and maturity [103-105]. The lack of use of planning frameworks and tools has been found to negatively affect the longevity of the strategic planning effort [106] and the use of available resources [107]. Lower levels of resource sustainability [108] and corporate performance have also been identified in SMEs [109]. On the other hand, a comprehensive strategic approach that adopts specific planning tools and frameworks has been found to improve SME performance [110] and market differentiation [111-113]. Formal strategic planning has also improved financial performance [114], management's commitment to the strategy [115], and the implementation of the strategy [116-121].

The planning and implementation of strategy in SMEs can benefit from the adaptation of various frameworks that can aid in sustainability, resilience building, and foresight [122-125]. The use of such tools has helped devise impactful strategies and better utilize the firm's resources [126-129].

\subsection{Achieving Strategic Alignment}

The requirement for PPM to be applied in the implementation of a strategy has been widely accepted $[25,44,99]$. Defining strategy has matured considerably and has been successfully performed in many organizations. However, the alignment of projects to a strategy and the successful implementation of these projects continues to be a challenge [130]. Among this challenge is the belief that a strategy is implemented through operations rather than projects. One of the goals of PPM is the strategic alignment of projects to the organizational strategy, which enables a greater level of executive and stakeholder engagement to support project success [131]. In addition, that strategy is delivered through a combination of operational work as well as projects by the PMI definition of PPM. 
Arlt [130] states that the goal of strategic alignment is defined through three aspects of alignment: "(1) strategic fit—the consistency of projects with the articulated strategy; (2) strategic contribution-the need to execute certain projects to achieve success with a certain strategy; and (3) strategic priorities - the dispensing of resources according to strategic importance." Strategic alignment is defined as the linking of project portfolios with the organizational vision, mission, and strategy [132,133], which aligns with the strategic planning requirements of SMEs. Furthermore, project portfolios are required to support the organization's vision and strategy and should aim to maximize the probability of achieving the organizational goals, vision, and mission [134].

\subsection{Balancing a Portfolio}

Selecting short- and long-term projects with various levels of risk within a portfolio once it is aligned is the second primary purpose of PPM [133] with various methods that have been introduced in the literature [135]. The concept of balance is a common aspect of business, as organizations need to balance a range of monetary and non-monetary goals as well as operational and project work.

Other considerations for balancing a portfolio include consideration of goal conflicts within selection decisions. One example could be a focus on cost savings versus strategic technology investments, requiring a compromise that reflects the trade-off between these two goals [134]. A portfolio should also provide a balanced mix of projects, taking into account different risk levels, time frames, and project sizes [136]. This requires negotiation and management between project stakeholders who have conflicting parameters or who require conflicting outcomes.

Cooper et al. [133] provided and extensive discussion on the balancing of portfolios and proposed a range of balancing dimensions which identify the relationship between risk and reward and the use of technology to devise strategic strengths.

The tracking and management of benefits is an important component of program and project portfolio management (PPM). In the case of PPM, benefits require being tracked and measured for the individual projects and for the portfolio. The tracking of benefits and time frames involved is a challenge for organizations and requires systems, processes, and technology. Again, in a strategic planning context, SMEs need to associate the investment in strategy with the expected medium-term benefits, drawing a further parallel between PPM and strategy implementation.

There is no clear and unified view on how to measure benefits for a project portfolio [134]. The literature suggests the use of traditional financial metrics for the determination of benefits, such as the net present value (NPV), return on investment (ROI), and internal rate of return (IRR), for the valuation of financial assets [25]. However, limitations occur if using financial metrics alone as projects, unlike capital assets, cannot be sold halfway through or treated as regular assets. Determination of their value due to sunk costs is significantly more difficult.

Other approaches, as outlined by Norrie [137], suggest a balanced view of financial and non-financial benefits tracking through the application of the triple bottom line and balanced scorecards (BSCs). It would be useful to apply the PPM model to a variety of strategic decisions that fall within the mid-range horizon of 2-4 years and to test the efficacy of this approach in both product- and service-oriented SMEs.

\subsection{Other Benefits of PPM}

There are a number of other benefits, as highlighted by Hadjinicolaou and Dumrak [70], and these include working on the right projects, spending in the right areas, stopping poor projects, gaps in the portfolio being identified and managed, removing project redundancies, and improved decision making.

Furthermore, other benefits include maximizing resource usage, demonstrating the value of key resources, and facilitating repeatable success, all of which are significant for 
improving organizational agility and business resilience. This enables innovation and the continuous improvement of PPM quality and maturity.

\subsection{Continuously Improving PPM Process Quality and Maturity and Reflections on SME Strategy}

Blomquist and Müller [102] referred to PPM process maturity as an important aspect of PPM implementation for continuously improving the decision-making process for project selection and process as well as the pipeline management process to improve the maturity of PPM. The pursuit of increased PPM maturity is viewed as driving not only the goals of PPM but also the maturity of project management and operational management. The PPM goals of improving strategic alignment and PPM implementation thereby improves project and organizational success to support innovation. When considering continuous improvement, the term "agile portfolio management" [138] has also been used and related to concepts or organizational agility and organizational resilience. The importance of a "dynamic capability" when managing project portfolios to support competitive advantages was also highlighted by [139]. Understanding the goals of PPM success outlined above will assist in the development of a PPM framework for the implementation of PPM to support project success. Through the use of this PPM approach, SME managers undertaking midrange planning may help achieve a better strategic alignment between the resources of the firm, the intended strategy, the level of maturity of the SME, and improvements in product or service quality [140].

The use of planning and implementation frameworks such as those used in PPM may improve the ability of a firm to use its resources [141-143], which enables a longer range of planning and resource allocation [144] and greater efficiency in strategy implementation [35,119] as well as financial performance [145] and sustainability [146]. The tendency to adopt frameworks has been shown to be dependent on executive attitudes toward the utility of such frameworks [127] and the firm's overall affinity to change, as well as its approach to performance management [9]. SME support systems used in strategic planning can help improve the overall efficiency of the strategic plan and the ability to implement it [147-151]

Further applied research is needed to identify the possible applications of the PPM model in SMEs from the inception stage of a strategy to the fulfillment of the firm's strategic goals.

\section{Conclusions}

This literature review and paper draws parallels between the use of PPM for the implementation of strategy and PfMM models that support not only PPM maturity but also project management and operational maturity to enhance strategic planning and innovation in SMEs who are looking at mid-term plans. The use of PPM provides a vehicle to not only improve projects but also operational management maturity in consideration that the strategy is implemented from the combination of projects as well as operational activities. However, the implementation of PPM also comes with its challenges which require significant planning and change management in their own right. There is also the assumption that the SME has a project portfolio of a sufficient size to justify the overhead of its use.

This study also outlines some of the benefits for innovation through the application of PPM to support project and organizational success for implementing strategies for medium-sized firms. This study makes a valuable contribution by collating a number of resources and references that can be used as inputs for an SME considering the use of PPM for strategy execution.

The literature review also provides insights into the ability of SMEs to innovate and suggests that the use of PPM methods and tools may enhance that capability, adding to the potential for the firm to not only innovate but absorb and apply that innovation. This work also points to potential opportunities in the use of PPM to aid managers in considering 
how to address markets in mid-term. Considering strategy through the use of PPM may enable the development of products and services that not only serve the current but also future markets.

This suggests that further research be conducted to examine the efficacy of applying PPM models in strategic decision making for smaller firms with the goal of improving strategic innovation, management foresight, and strategic implementation. It proposes that managers consider various scaled PPM models and tools in their planning and implementation of strategies. This paper forms part of a broader body of work that will test the application of these concepts in SME businesses in Australia who have struggled to develop and implement strategies beyond the COVID-19 pandemic and explore the possibilities for SMEs in local as well as in international markets to adapt PPM and PfMM tools for their strategic business needs.

Future research efforts can benefit from this examination by developing PPM benefit management so that the required benefits can be maintained or enhanced in the context of strategic planning and foresight for SMEs. However, it is important that barriers to strategic framework implementation, especially the barriers preventing SMEs from success, must be minimized or mitigated through the examination of the possible uses of PPM tools and frameworks to design and develop strategic plans for SMEs.

The original findings of the practical implications of this study include the potential for SMEs to innovate using existing PPM tools and methods to enhance their ability to apply strategic foresight, to plan, and to potentially achieve a form of ambidexterity in their current and future markets.

Author Contributions: Conceptualization, review and editing, N.H., M.K. and I.A. All authors have read and agreed to the published version of the manuscript.

Funding: The publication of this article for the 11th International Conference on Engineering, Project and Production Management-EPPM2021 was financed in the framework of contract no. DNK/SN/465770/2020 by the Ministry of Science and Higher Education within the "Excellent Science" program.

Institutional Review Board Statement: Not applicable.

Informed Consent Statement: Not applicable.

Data Availability Statement: The study did not report any data.

Conflicts of Interest: The authors declare no conflict of interest.

\section{References}

1. Schlegelmilch, B.B.; Diamantopoulos, A.; Kreuz, P. Strategic innovation: The construct, its drivers and its strategic outcomes. J. Strat. Mark. 2003, 11, 117-132. [CrossRef]

2. Lehmann-Ortega, L.; Schoettl, J.M. From buzzword to managerial tool: The role of business models in strategic innovation. CLADEA Santiago Chile. 2005, pp. 1-14. Available online: http://www.bmcommunity.sitew.com/fs/Root/8jvaaBusinessmodelsantiago.pdf (accessed on 23 November 2021).

3. Papke-Shields, K.E.; Boyer-Wright, K.M. Strategic planning characteristics applied to project management. Int. J. Proj. Manag. 2017, 35, 169-179. [CrossRef]

4. Berge, Z.L.; Smith, D.L. Implementing Corporate Distance Training Using Change Management, Strategic Planning and Project Management. In Distance Learning Technologies; IGI Global: Hershey, PA, USA, 2000; pp. 39-51.

5. Poister, T.H. The Future of Strategic Planning in the Public Sector: Linking Strategic Management and Performance. Public Adm. Rev. 2010, 70, s246-s254. [CrossRef]

6. León-Soriano, R.; Muñoz-Torres, M.J.; Chalmeta, R. Methodology for sustainability strategic planning and management. Ind. Manag. Data Syst. 2010, 110, 249-268. [CrossRef]

7. Teixeira, G.F.G.; Junior, O.C. How to make strategic planning for corporate sustainability? J. Clean. Prod. 2019, $230,1421-1431$. [CrossRef]

8. Platje, A.; Seidel, H.; Wadman, S. Project and portfolio planning cycle: Project-based management for the multiproject challenge. Int. J. Proj. Manag. 1994, 12, 100-106. [CrossRef]

9. Tapinos, E.; Dyson, R.; Meadows, M. The impact of performance measurement in strategic planning. Int. J. Prod. Perform. Manag. 2005, 54, 370-384. [CrossRef] 
10. Aldehayyat, J.S.; Al Khattab, A.A.; Anchor, J.R. The use of strategic planning tools and techniques by hotels in Jordan. Manag. Res. Rev. 2011, 34, 477-490. [CrossRef]

11. Clark, D.N. A literature analysis of the use of management science tools in strategic planning. J. Oper. Res. Soc. 1993, 43, 859-870. [CrossRef]

12. Abd Ghani, K.D.; Nayan, S.; Mohd Ghazali, S.A.; Shafie, L.A.; Nayan, S. Critical internal and external factors that affect firms strategic planning. Int. Res. J. Financ. Econ. 2010, 51, 50-58.

13. Gallop, G. Strategic planning: Is it the new model? Public Adm. Today 2007, 28-33. [CrossRef]

14. Song, M.; Im, S.; Van Der Bij, H.; Song, L.Z. Does Strategic Planning Enhance or Impede Innovation and Firm Performance? J. Prod. Innov. Manag. 2011, 28, 503-520. [CrossRef]

15. Tse, T. Paradox resolution: A means to achieve strategic innovation. Eur. Manag. J. 2013, 31, 682-696. [CrossRef]

16. Faghih, N.; Dastourian, B.; Sajadi, S.M.; Henten, A.; Foroudi, P. A framework for business model with strategic innovation in ICT firms: The importance of information. Bottom Line 2018. [CrossRef]

17. Sammut-Bonnici, T.; Paroutis, S. Developing a dominant logic of strategic innovation. Manag. Res. Rev. 2013, 36, 924-938. [CrossRef]

18. Markides, C. Strategic innovation in established companies. MIT Sloan Manag. Rev. 1998, 39, 31.

19. Baden-Fuller, C. Strategic Innovation, Corporate Entrepreneurship and Matching Outside-in to Inside-out Approaches to Strategy Research. Br. J. Manag. 1995, 6, S3-S16. [CrossRef]

20. Kopmann, J.; Kock, A.; Killen, C.P. Project portfolio management: The linchpin in strategy processes. Camb. Handb. Organ. Proj. Manag. 2017. [CrossRef]

21. Voss, M.; Kock, A. Impact of relationship value on project portfolio success: Investigating the moderating effects of portfolio characteristics and external turbulence. In. J. Proj. Manage. 2013, 31, 847-861. [CrossRef]

22. Jonas, D. Empowering project portfolio managers: How management involvement impacts project portfolio management performance. Int. J. Proj. Manag. 2010, 28, 818-831. [CrossRef]

23. Jonas, D.; Kock, A.; Gemünden, H.G. Predicting Project Portfolio Success by Measuring Management Quality—A Longitudinal Study. IEEE Trans. Eng. Manag. 2012, 60, 215-226. [CrossRef]

24. Beringer, C.; Jonas, D.; Kock, A. Behavior of internal stakeholders in project portfolio management and its impact on success. Int. J. Proj. Manag. 2013, 31, 830-846. [CrossRef]

25. Archer, N.; Ghasemzadeh, F. An integrated framework for project portfolio selection. Int. J. Proj. Manag. 1999, 17, 207-216. [CrossRef]

26. Unger, B.N.; Kock, A.; Gemünden, H.G.; Jonas, D. Enforcing strategic fit of project portfolios by project termination: An empirical study on senior management involvement. Int. J. Proj. Manag. 2012, 30, 675-685. [CrossRef]

27. Killen, C.P.; Kleinschmidt, E.J.; Hunt, R.A. Project portfolio management for product innovation. Int. J. Qual. Reliab. Manag. 2008 25, 24-38. [CrossRef]

28. Ul Musawir, A.; Abd-Karim, S.B.; Mohd-Danuri, M.S. Project governance and its role in enabling organizational strategy implementation: A systematic literature review. Int. J. Proj. Manag. 2020, 38, 1-6. [CrossRef]

29. Raisch, S.; Birkinshaw, J.; Probst, G.; Tushman, M.L. Organizational am-bidexterity: Balancing exploitation and exploration for sustained performance. Organ. Sci. 2009, 20, 685-695. [CrossRef]

30. Pedersen, C.L.; Ritter, T. The four executive challenges of project-based strategy. Strat. Leadersh. 2018, 46, 44-49. [CrossRef]

31. Löwstedt, M.; Räisänen, C.; Leiringer, R. Doing strategy in project-based organizations: Actors and patterns of action. Int. J. Proj. Manag. 2018, 36, 889-898. [CrossRef]

32. Hines, A.; Slaughter, R.A. Thinking about the Future: Guidelines for Strategic Foresight; Bishop, P.J., Ed.; Social Technologies: Washington, DC, USA, 2006.

33. Blichfeldt, B.S.; Eskerod, P. Project portfolio management-There's more to it than what management enacts. Int. J. Proj. Manag. 2008, 26, 357-365. [CrossRef]

34. Hang, X.; Wang, C. Strategic decision-making in small and medium-sized enterprises: Evidence from Australia. Int. J. Bus. Stud. Publ. Fac. Bus. Adm. Ed. Cowan Univ. 2012, 20, 91-110.

35. O'Regan, N.; Ghobadian, A. Formal strategic planning: Annual raindance or wheel of success? Strat. Chang. 2007, 16, 11-22. [CrossRef]

36. Kale, E.; Aknar, A.; Başar, Ö. Absorptive capacity and firm performance: The mediating role of strategic agility. Int. J. Hosp. Manag. 2019, 78, 276-283. [CrossRef]

37. Margherita, A.; Sharifi, H.; Caforio, A. A conceptual framework of strategy, action and performance dimensions of organisational agility development. Technol. Anal. Strat. Manag. 2021, 33, 829-842. [CrossRef]

38. Salehzadeh, R.; Pool, J.K.; Mohseni, A.M.; Tahani, G. Factors influencing organisational performance: The role of knowledge sharing and organisational agility. Int. J. Bus. Excell. 2017, 11, 344-356. [CrossRef]

39. Tushman, M.L.; O’Reilly, C.A., III. Ambidextrous organizations: Managing evolutionary and revolutionary change. Calif. Manag. Rev. 1996, 38, 8-29. [CrossRef]

40. O'Reilly, C.A.; Tushman, M.L. Organizational Ambidexterity: Past, Present, and Future. Acad. Manag. Perspect. 2013, 27, 324-338. [CrossRef] 
41. Project Management Institute (PMI). Winning through Project Portfolio Management: The Practitioner's Perspective; Project Management Institute: Newtown Square, PA, USA, 2015.

42. Gutiérrez, E.; Magnusson, M. Dealing with legitimacy: A key challenge for Project Portfolio Management decision makers. Int. J. Proj. Manag. 2014, 32, 30-39. [CrossRef]

43. Martinsuo, M.; Lehtonen, P. Role of single-project management in achieving portfolio management efficiency. Int. J. Proj. Manag. 2007, 25, 56-65. [CrossRef]

44. Meskendahl, S. The influence of business strategy on project portfolio management and its success-A conceptual framework. Int. J. Proj. Manag. 2010, 28, 807-817. [CrossRef]

45. Vedel, J.B.; Geraldi, J. A 'stranger' in the making of strategy: A process perspective of project portfolio management in a pharmaceutical firm. Int. J. Proj. Manag. 2020, 38, 454-463. [CrossRef]

46. El Hannach, D.; Marghoubi, R.; El Akkaoui, Z.; Dahchour, M. Analysis and Design of a Project Portfolio Management System. Comput. Inf. Sci. 2019, 12, 42-57. [CrossRef]

47. Martinsuo, M. Project portfolio management in practice and in context. Int. J. Proj. Manag. 2013, 31, 794-803. [CrossRef]

48. Kharat, V.J.; Bhukya, K.R. Best practices in project portfolio management for dynamic decision making. J. Mod. Proj. Manag. 2018, 6. [CrossRef]

49. Kock, A.; Heising, W.; Gemünden, H.G. A Contingency Approach on the Impact of Front-End Success on Project Portfolio Success. Proj. Manag. J. 2016, 47, 115-129. [CrossRef]

50. Kopmann, J.; Kock, A.; Killen, C.; Gemunden, H.G. Business Case Control in Project Portfolios-An Empirical Investigation of Performance Consequences and Moderating Effects. IEEE Trans. Eng. Manag. 2015, 62, 529-543. [CrossRef]

51. Kopmann, J.; Kock, A.; Killen, C.P.; Gemünden, H.G. The role of innovation portfolio management in the nexus between deliberate and emergent innovation strategies. In Proceedings of the International Product Development Management Conference, Limerick, Ireland, 14-17 June 2014; EIASM: Brussels, Belgium, 2014.

52. Teller, J.; Unger, B.N.; Kock, A.; Gemünden, H.G. Formalization of project portfolio management: The moderating role of project portfolio complexity. Int. J. Proj. Manag. 2012, 30, 596-607. [CrossRef]

53. De Reyck, B.; Grushka-Cockayne, Y.; Lockett, M.; Calderini, S.R.; Moura, M.; Sloper, A. The impact of project portfolio management on information technology projects. Int. J. Proj. Manag. 2005, 23, 524-537. [CrossRef]

54. Padovani, M.; Carvalho, M.M. Integrated PPM Process: Scale Development and Validation. Int. J. Proj. Manag. 2016, 34, 627-642. [CrossRef]

55. Kaiser, M.G.; El Arbi, F.; Ahlemann, F. Successful project portfolio management beyond project selection techniques: Understanding the role of structural alignment. Int. J. Proj. Manag. 2015, 33, 126-139. [CrossRef]

56. Ibbs, C.; Kwak, Y. The Benefits of Project Management; Project Management Institute: Newtown Square, PA, USA, 1997.

57. Young, M.; Young, R.; Zapata, J.R. Project, programme and portfolio maturity: A case study of Australian Federal Government. Int. J. Manag. Proj. Bus. 2014, 7, 215-230. [CrossRef]

58. Yazici, H.J. The Role of Project Management Maturity and Organizational Culture in Perceived Performance. Proj. Manag. J. 2009, 40, 14-33. [CrossRef]

59. Backlund, F.; Chronéer, D.; Sundqvist, E. Project management maturity models-A critical review: A case study within Swedish engineering and construction organizations. Procedia-Soc. Behav. Sci. 2014, 119, 837-846. [CrossRef]

60. Görög, M. A broader approach to organisational project management maturity assessment. Int. J. Proj. Manag. 2016, 34, 1658-1669. [CrossRef]

61. Pennypacker, J.S.; Grant, K.P. Project Management Maturity: An Industry Benchmark. Proj. Manag. J. 2003, 34, 4-11. [CrossRef]

62. Miklosik, A. Improving Project Management Performance through Capability Maturity Measurement. Procedia Econ. Financ. 2015, 30, 522-530. [CrossRef]

63. Bushuyev, S.; Verenych, O. Organizational maturity and project: Program and portfolio success. In Developing Organizational Maturity for Effective Project Management; IGI Global: Hershey, PA, USA, 2018; pp. 104-127.

64. Abdul Rasid, S.Z.; Wan Ismail, W.K.; Mohammad, N.H.; Long, C.S. Assessing adoption of project management knowledge areas and maturity level: Case study of a public agency in Malaysia. J. Manag. Eng. 2014, 30, 264-271. [CrossRef]

65. Langston, C.; Ghanbaripour, A.N. A Management Maturity Model (MMM) for project-based organisational performance assessment. Constr. Econ. Build. 2016, 16, 68-85. [CrossRef]

66. Anantatmula, V.; Rad, P. Linkages among project management maturity, PMO, and project success. In Proceedings of the 2013 International Conference on Engineering, Technology and Innovation (ICE) \& IEEE International Technology Management Conference, The Hague, The Netherlands, 24-26 June 2013; pp. 1-12.

67. Aubry, M.; Hobbs, B. A Fresh Look at the Contribution of Project Management to Organizational Performance. Proj. Manag. J. 2011, 42, 3-16. [CrossRef]

68. Hurt, M.; Thomas, J.L. Building Value through Sustainable Project Management Offices. Proj. Manag. J. 2009, 40, 55-72. [CrossRef]

69. Hobbs, B.; Aubry, M.; Thuillier, D. The project management office as an organisational innovation. Int. J. Proj. Manag. 2008, 26, 547-555. [CrossRef]

70. Hadjinicolaou, N.; Dumrak, J. Investigating Association of Benefits and Barriers in Project Portfolio Management to Project Success. Procedia Eng. 2017, 182, 274-281. [CrossRef]

71. Dahles, H.; Susilowati, T.P. Business resilience in times of growth and crisis. Ann. Tour. Res. 2015, 51, 34-50. [CrossRef] 
72. Torres, A.P.; Marshall, M.I.; Sydnor, S. Does social capital pay off? The case of small business resilience after Hurricane Katrina. J. Contingencies Crisis Manag. 2019, 27, 168-181. [CrossRef]

73. Tompkins, J.A. 4 Steps to Business Resilience. Ind. Manag. 2007, 49, 14-18.

74. Tibay, V.; Miller, J.; Chang-Richards, A.; Egbelakin, T.; Seville, E.; Wilkinson, S. Business resilience: A study of Auckland hospitality sector. Procedia Eng. 2018, 212, 1217-1224. [CrossRef]

75. Aldianto, L.; Anggadwita, G.; Permatasari, A.; Mirzanti, I.; Williamson, I. Toward a Business Resilience Framework for Startups. Sustainability 2021, 13, 3132. [CrossRef]

76. Heising, W. The integration of ideation and project portfolio management-A key factor for sustainable success. Int. J. Proj. Manag. 2012, 30, 582-595. [CrossRef]

77. Ayala, J.-C.; Manzano, G. The resilience of the entrepreneur. Influence on the success of the business. A longitudinal analysis. J. Econ. Psychol. 2014, 42, 126-135. [CrossRef]

78. Hadi, S. New perspective on the resilience of SMEs proactive, adaptive, reactive from business turbulence: A systematic review. $J$ Xi'an Univ. Arch. Technol. 2020, 12, 1265-1275.

79. Soroka, A.; Bristow, G.; Naim, M.; Purvis, L. Measuring regional business resilience. Reg. Stud. 2019, 54, 838-850. [CrossRef]

80. Saad, M.H.; Hagelaar, G.; van der Velde, G.; Omta, S.W.F. Conceptualization of SMEs' business resilience: A systematic literature review. Cogent Bus. Manag. 2021, 8, 1938347. [CrossRef]

81. Kral, P.; Valjaskova, V.; Janoskova, K. Quantitative approach to project portfolio management: Proposal for Slovak companies. Oeconomia Copernic. 2019, 10, 797-814. [CrossRef]

82. Van Oosterhout, M.; Waarts, E.; van Hillegersberg, J. Assessing business agility: A multi-industry study in the Netherlands. In Business Agility and Information Technology Diffusion; Springer: Boston, MA, USA, 2005; pp. 275-294.

83. Qosasi, A.; Permana, E.; Muftiadi, A.; Purnomo, M.; Maulina, E. Building SMEs' Competitive Advantage and the Organizational Agility of Apparel Retailers in Indonesia: The role of ICT as an Initial Trigger. Gadjah Mada Int. J. Bus. 2019, 21, 69-91. [CrossRef]

84. Denning, S. The quest for genuine business agility. Strat. Leadersh. 2019, 48, 21-28. [CrossRef]

85. Siew, R.Y.J. Integrating sustainability into construction project portfolio management. KSCE J. Civil Eng. 2016, 20, 101-108. [CrossRef]

86. Shin, H.; Lee, J.N.; Kim, D.; Rhim, H. Strategic agility of Korean small and medium enter-prises and its influence on operational and firm performance. Int. J. Prod. Econ. 2015, 168, 181-196. [CrossRef]

87. Nyamrunda, F.C.; Freeman, S. Strategic agility, dynamic relational capability and trust among SMEs in transitional economies. J. World Bus. 2021, 56, 101175. [CrossRef]

88. Laslo, Z. Project portfolio management: An integrated method for resource planning and scheduling to minimize planning/scheduling-dependent expenses. Int. J. Project Manag. 2010, 28, 609-618. [CrossRef]

89. Saidia, A.A.; Ayodele, M.S.; Maxwell, W.P. Firm level strategy and value creation in small businesses: The Nigerian experience. Gadjah Mada Int. J. Bus. 2021, 23, 193-214.

90. Kim, E.; Euh, Y.; Yoo, J.; Lee, J.G.; Jo, Y.; Lee, D. Which business strategy improves ICT startup companies' technical efficiency? Technol. Anal. Strateg. Manag. 2021, 33, 843-856. [CrossRef]

91. Kreiser, P.M.; Kuratko, D.F.; Covin, J.G.; Ireland, R.D.; Hornsby, J.S. Corporate entrepreneurship strategy: Extending our knowledge boundaries through configuration theory. Small Bus. Econ. 2021, 56, 739-758. [CrossRef]

92. Alsaad, M.A. Business Incubators: A Strategy for College Sustainability in Higher Education an Exploratory Study at Al-Kunooz University College/Basra. J. Small Bus. Entrep. 2021, 9, 1-14. [CrossRef]

93. Cosenz, F.; Bivona, E. Fostering growth patterns of SMEs through business model innovation. A tailored dynamic business modelling approach. J. Bus. Res. 2021, 130, 658-669. [CrossRef]

94. Ahimbisibwe, G.M.; Ntayi, J.M.; Ngoma, M.; Bakunda, G.; Munene, J.C.; Esemu, T. Entrepreneurial Mindset: Examining the Contribution of Deliberative and Implemental Mindsets to SME Internationalization. J. Small Bus. Strat. 2021, 31, 47-58. [CrossRef]

95. González-Díaz, R.R.; Guanilo-Gómez, S.L.; Acevedo-Duque, Á.E.; Campos, J.S.; Vargas, E.C. Intrinsic alignment with strategy as a source of business sustainability in SMEs. Entrep. Sustain. Issues 2021, 8, 377-388. [CrossRef]

96. Lindsey, K.; Mauck, N.; Olsen, B. The coming wave of small business succession and the role of stakeholder synergy theory. Glob. Financ. J. 2021, 48, 100457. [CrossRef]

97. Wuen, C.H.; Ibrahim, F.; Ringim, K.J. Mediating effect of competitive strategy in the relationship between strategic human resource management and performance of small and medium enterprises in Brunei Darussalam. Middle East J. Manag. 2021, 8, 254-277. [CrossRef]

98. Gasparin, M.; Green, W.; Lilley, S.; Quinn, M.; Saren, M.; Schinckus, C. Business as unusual: A business model for social innovation. J. Bus. Res. 2021, 125, 698-709. [CrossRef]

99. Petrinska-Labudovikj, R. Project portfolio management in theory and practice. MEST J. 2014, 2, 192-203. [CrossRef]

100. Arlt, M. Advancing the Maturity of Project Portfolio Management through Methodology and Metrics Refinements. Ph.D. Thesis, RMIT University, Melbourne, Australia, 2010.

101. Danesh, D.; Ryan, M.J.; Abbasi, A. A systematic comparison of multi-criteria decision making methods for the improvement of project portfolio management in complex organisations. Int. J. Manag. Decis. Mak. 2017, 16, 280-320. 
102. Blomquist, T.; Müller, R. Practices, Roles, and Responsibilities of Middle Managers in Program and Portfolio Management. Proj. Manag. J. 2006, 37, 52-66. [CrossRef]

103. Fedouaki, F.; Okar, C.; El Alami, S. A maturity model for Business Intelligence System project in Small and Medium-sized Enterprises: An empirical investigation. Int. J. Comput. Sci. Issues (IJCSI) 2013, 61.

104. Zhang, Z.-L.; Dai, F.-S. Application of Quality Management Maturity Assessment System in Small and Medium-Sized Enterprises. In Proceedings of the International Asia Conference on Industrial Engineering and Management Innovation (IEMI2012), Heidelberg, Germany, 22-24 August 2013; Springer: Berlin, Germany, 2013; pp. 649-656.

105. Virkkala, P.; Saarela, M.; Hänninen, K.; Kujala, J.; Simunaniemi, A.-M. Business Maturity Models for Small and Medium-Sized Enterprises: A Systematic Literature Review. Management 2020, 15, 137-155. [CrossRef]

106. McDowell, W.C.; Harris, M.L.; Geho, P.R. Longevity in small business: The effect of maturity on strategic focus and business performance. J. Bus. Res. 2016, 69, 1904-1908. [CrossRef]

107. Mount, J.; Zinger, J.; Forsyth, G.R. Organizing for development in the small business. Long Range Plan. 1993, 26, 111-120. [CrossRef]

108. Meza-Ruiz, I.D.; Rocha-Lona, L.; del Rocío Soto-Flores, M.; Garza-Reyes, J.A.; Kumar, V.; Lopez-Torres, G.C. Measuring business sustainability maturity-levels and best practices. Procedia Manuf. 2017, 11, 751-759. [CrossRef]

109. Aldehayyat, J.; Twaissi, N. Strategic Planning and Corporate Performance Relationship in Small Business Firms: Evidence from a Middle East Country Context. Int. J. Bus. Manag. 2011, 6, 255. [CrossRef]

110. Williams, R.I., Jr.; Manley, S.C.; Aaron, J.R.; Daniel, F. The relationship between a comprehensive strategic approach and small business performance. J. Small Bus. Strategy 2018, 28, 33-48.

111. Nwachukwu, O.C. CEO Locus of Control, Strategic Planning, Differentiation, And Small Business Performance: A Test of a Path Analytic Model. J. Appl. Bus. Res. (JABR). 2011, 11, 9-14. [CrossRef]

112. Kohtamäki, M.; Kautonen, T.; Kraus, S. Strategic planning and small business performance: An examination of the mediating role of exploration and exploitation behaviours. Int. J. Entrep. Innov. 2010, 11, 221-229. [CrossRef]

113. Cordeiro, W. Small businesses ignore strategic planning at their peril. Acad. Bus. Res. J. 2013, 3, 1-9.

114. Schwenk, C.R.; Shrader, C. Effects of Formal Strategic Planning on Financial Performance in Small Firms: A Meta-Analysis. Entrep. Theory Pract. 1993, 17, 53-64. [CrossRef]

115. Gibb, A.; Scott, M. Strategic awareness, personal commitment and the process of planning in the small business. J. Manag. Stud. 1985, 22, 597-631. [CrossRef]

116. Kutllovci, E.; Shala, V. The Role of Strategic Management on Small Business Growth in Kosovo. Int. J. Bus. Soc. Res. 2013, 3. [CrossRef]

117. Shuman, J.C.; Shaw, J.J.; Sussman, G. Strategic planning in smaller rapid growth companies. Long Range Plan. 1985, 18, 48-53. [CrossRef]

118. Watts, L.R.; Ormsby, J.G. The effect of operational and strategic planning on small firm performance. J. Small Bus. Strategy. 1990, 1, 27-35.

119. Gibbons, P.T.; O'Connor, T. Influences on Strategic Planning Processes among Irish SMEs. J. Small Bus. Manag. 2005, 43, 170-186. [CrossRef]

120. Mueller, C.B.; Naffziger, D.W. Strategic planning in small firms: Activity and process realities. J. Small Bus. Strategy. 1999, 10, 78-85.

121. Ida, S.; Ramli, A.; Mustafa, M.; Yusoff, R.Z. Strategic planning and firm performance: A proposed framework. Int. Acad. Res. J. Bus. Technol. 2015, 1, 201-207.

122. Davig, W.; Elbert, N.; Brown, S. Implementing a strategic planning model for small manufacturing firms: An adaptation of the balanced scorecard. SAM Adv. Manag. J. 2004, 69, 18.

123. Kraus, S.; Harms, R.; Schwarz, E. Strategic business planning and success in small firms. Int. J. Entrep. Innov. Manag. 2008, 8, 381. [CrossRef]

124. Trainer, J.F. Models and tools for strategic planning. New Dir. Inst. Res. 2004, 2004, 129-138. [CrossRef]

125. Glaister, K.W.; Falshaw, J.R. Strategic planning: Still going strong? Long Range Plan. 1999, 32, 107-116. [CrossRef]

126. Al Ghamdi, S.M. The use of strategic planning tools and techniques in Saudi Arabia: An empirical study. Int. J. Manag. 2005, 22, 376.

127. Kalkan, A.; Bozkurt, Ö.Ç. The choice and use of strategic planning tools and techniques in Turkish SMEs according to attitudes of executives. Procedia-Soc. Behav. Sci. 2013, 99, 1016-1025. [CrossRef]

128. Heracleous, L. Strategic thinking or strategic planning? Long Range Plan. 1998, 31, 481-487. [CrossRef]

129. Baker, G.A.; Leidecker, J.K. Does it pay to plan? Strategic planning and financial performance. Agribus. Int. J. 2001, 17, 355-364. [CrossRef]

130. Schipper, R.R.; Silvius, A.G. Towards a conceptual framework for sustainable project portfolio management. Int. J. Proj. Organ. Manag. 2018, 10, 191-221. [CrossRef]

131. Lerch, M.; Spieth, P. Innovation project portfolio management: A meta-analysis. Int. J. Prod. Dev. 2012, 16, 77-94. [CrossRef]

132. Belaid, F. Decision-making process for project portfolio management. Int. J. Serv. Oper. Inform. 2011, 6, 160-181. [CrossRef]

133. Cooper, R.G.; Edgett, S.J.; Kleinschmidt, E.J. Portfolio Management for New Products; Basic Books: Cambridge, MA, USA, 2001. 
134. Linhart, A.; Röglinger, M.; Stelzl, K. A project portfolio management approach to tackling the exploration/exploitation trade-off. Bus. Inf. Syst. Eng. 2020, 62, 103-119. [CrossRef]

135. Caron, F.; Fumagalli, M.; Rigamonti, A. Engineering and contracting projects: A value at risk based approach to portfolio balancing. Int. J. Proj. Manag. 2007, 25, 569-578. [CrossRef]

136. Artto, K.A.; Martinsuo, M.; Aalto, T. Project Portfolio Management: Strategic Management through Projects; Project Management Association Finland: Helsinki, Finland, 2001.

137. Norrie, J. Improving Results of Project Portfolio Management in the Public Sector Using a Balanced Strategic Scoring Model; School of Property, Construction and Project Management, Design and Social Context, RMIT University: Melbourne, Australia, 2006.

138. Krebs, J. Agile Portfolio Management; Microsoft Press: Redmond, WA, USA, 2009.

139. Killen, C.; Hunt, R. Dynamic capability: Understanding the relationship between project portfolio management capability and competitive advantage. In Proceedings of the PMI Research \& Education Conference, Washington, DC, USA, 11-14 July 2010; Project Management Institute: Newtown Square, PA, USA, 2010; pp. 1-26.

140. Wu, Y.; Li, J.; Wang, J.; Huang, Y. Project portfolio management applied to building energy projects management system. Renew. Sustain. Energy Rev. 2012, 16, 718-724. [CrossRef]

141. Kraus, S.; Reiche, B.S.; Reschke, C.H. The role of strategic planning in SMEs: Literature review and implications. In Proceedings of the Annual Meeting of the British Academy of Management, Warwick, UK, 10 September 2007.

142. Vargo, J.; Seville, E. Crisis strategic planning for SMEs: Finding the silver lining. Int. J. Prod. Res. 2011, 49, 5619-5635. [CrossRef]

143. Cheng, W.H.; Abdul Kadir, K.; Bohari, A.M. The strategic planning of SMEs in Malaysia: A view of external environmental scanning. Int. J. Bus. Soc. 2014, 15, 437-446.

144. Kraus, S.; Reiche, B.S.; Reschke, C.H. Implications of strategic planning in SMEs for international entrepreneurship research and practice. In Energizing Management through Innovation and Entrepreneurship; Routledge: London, UK, 2008; pp. $128-145$.

145. McKiernan, P.; Morris, C. Strategic Planning and Financial Performance in UK SMEs: Does Formality Matter? Br. J. Manag. 1994, 5, S31-S41. [CrossRef]

146. Khan, M.K.; Zahid, R.M.A.; Saleem, A.; Sági, J. Board Composition and Social \& Environmental Accountability: A Dynamic Model Analysis of Chinese Firms. Sustainability 2021, 13, 10662.

147. Kitsios, F.; Kamariotou, M. Decision support systems and strategic planning: Information technology and SMEs' performance. Int. J. Decis. Support Syst. 2018, 3, 53-70. [CrossRef]

148. AlQershi, N. Strategic thinking, strategic planning, strategic innovation and the performance of SMEs: The mediating role of human capital. Manag. Sci. Lett. 2021, 11, 1003-1012. [CrossRef]

149. AlQershi, N.A.; Bin Abas, Z.; Mokhtar, S.S.M. The intervening effect of structural capital on the relationship between strategic innovation and manufacturing SMEs' performance in Yemen. Manag. Sci. Lett. 2021, 11, 21-30. [CrossRef]

150. Dubihlela, J.; Sandada, M. Impact of Strategic Planning on Small and Medium-Sized Enterprises' (SMEs) Performance: The Role of Employee Participation, Implementation Incentives and Evaluation and Control. J. Econ. 2014, 5, 45-55. [CrossRef]

151. Muhammad Siddique, C. A comparative study of strategic planning practices of SMEs and large-sized business organizations in emerging economies: The case of UAE. Strateg. Chang. 2015, 24, 553-567. [CrossRef] 